\title{
The Participation of Fisherman Groups in Community Empowerment Activities (A Study of Community-Based Coral Reef Rehabilitation in Baurung, Banggae Timur, Majene)
}

\author{
Muhammad Muhtaj Qadir ${ }^{\text {* }}$, Budhi Gunawan², Iskandar ${ }^{3}$ \\ ${ }^{1}$ Department of Environmental Science, Graduate School, Universitas Padjadjaran \\ ${ }^{2}$ Department of Anthropology, FISIP, Universitas Padjadjaran \\ ${ }^{3}$ Departement of Fishery, Universitas Padjadjaran \\ * Author Correspondence. Email: muhammad17134@mail.unpad.ac.id \\ Received: 28 August 2020; Revised: 04 February 2021; Accepted: 29 Maret 2021
}

\begin{abstract}
This study aims to describe (1) the comprehensive implementation of coral reef rehabilitation activities which have been carried out in Baurung Village, Banggae Timur District, Majene Regency, Sulawesi Barat, and (2) the participation of fisherman groups who have been directly involved in the coral reef rehabilitation activities. This study employs qualitative methods which data are collected through observation and interviews. The research participants were selected through purposive sampling and involved activity executor and the Head of the Fisherman Group from Samaelo dan Sipatuo. The results demonstrated that (1) The implementation of coral reef rehabilitation activities was carried out in four stages, namely preparation, implementation, monitoring/evaluation and maintenance, (2) The participation of fisherman groups shows that in the preparation and implementation stages, their participation is considered high, while their participation in monitoring/evaluation and maintenance stages tends to decrease. Therefore, it brings an impact to the activity results.
\end{abstract}

Keywords: rehabilitation activities, participation, fisherman group

How to Cite: Qadir, M.M., Budhi, G., \& Iskandar. (2021). The Participation of Fisherman Groups in Community Empowerment Activities (A Study of CommunityBased Coral Reef Rehabilitation in Baurung, Banggae Timur, Majene). JPPM (Jurnal Pendidikan dan Pemberdayaan Masyarakat), 8(2), 147-158. doi: 10.21831/jppm.v8i2.40172

\section{Introduction}

In tropical countries such as Indonesia, coral reefs have served a significant role in providing ecological benefits and high economic value for the community, especially in the coastal areas such as in the study conducted by Suhasono (2007) in Sjafrie (2010), which has calculated the economic value of coral reefs from fishery products in Takabonerate, South Sulawesi and obtained US\$ $777 / \mathrm{km}^{2}$ as its result.

The worldwide coral reefs, including those in Indonesia, have undergone threats due to natural and human factors. According to Edward and Gomez (2007), damages to coral reefs were resulted from natural disasters like earthquakes, tsunamis, hurricanes, global warming (bleaching), predators (Acanthaster planci, Drupella), acidification, openness due to low tides, longer sunlight exposure, and disease. Meanwhile, the human factors include the use of explosives, coral mining, tourism, anchor disposal, solid and liquid waste disposal (Syakir et.al., 2015) as well as illegal exploitation of corals for trading (Ramses, 2018).

Banggae Timur District in Majene Regency is one of the areas which has experienced fairly severe damage of coral reef ecosystems. According to an 
JPPM (Jurnal Pendidikan dan Pemberdayaan Masyarakat), 8 (2), 2021 - 148

Muhammad Muhtaj Qadir, Budhi Gunawan, Iskandar

environmental NGO in Majene, the damage to coral reefs in Banggae Timur was caused by the activities of local and immigrant fishermen who do fishing activities which are not environmentally friendly. This is reinforced by the data from the Department of Marine Affairs and Fisheries of Majene Regency in 2013 which state that Banggae Timur has only live coral coverage around $20 \%-38 \%$ and they are in the critical category (Office of Marine and Fishery Service in Majene, 2013). Several improvements have been made responding to the coral reef damage. One of which was carried out by several lecturers from the University of West Sulawesi in 2016 through coral reef rehabilitation activities in one of the villages in Banggae Timur, namely Baurung Village.

According to the Coral Reef Rehabilitation Guidelines issued by the Directorate of Conservation and Biodiversity (2015), it is stated that one of the effective attempts of coral reef management is coral reef rehabilitation. Recovery procedures in coral reef rehabilitation activities such as coral transplantation methods are considered quite effective in restoring coral reef conditions such as that documented in the study by Dhaiyat, et al. (2003) which reveals that coral transplantation in general has a survival rate of $50-100 \%$. In addition, coral transplantation techniques have been widely implemented in several provinces in Indonesia (Zulfikar \& Soedharma, 2008). Hence, the coral restoration activities in Baurung Village utilizes the coral reef rehabilitation procedures using the coral transplantation method as an alternative to damaged coral restoration.

In supporting coral reef rehabilitation in Baurung, the project executors empowered local fishermen in the village. The number of fishermen who participated in the rehabilitation consists of $\mathbf{2 2}$ fishermen and were divided into two groups called Sipatuo and Samaelo groups. This number was considered a small scale and it was adjusted to the number of corals to be transplanted. In addition, with these members, it will be easier to manage their roles and provide knowledge and skills as what had been carried out in Lake Alaorta, Madagascar, which proved that a small-scale communitybased conservation is always much more promising than large-scale conservation which frequently fails (Lammers, 2017).

In principle, coral reef rehabilitation in Baurung does not only focus on improvements in the ecological sector, but also focus on social aspects, which entail raising an awareness and developing skills for participating fishermen. Empowered fishermen are expected to participate in all series of activities as the coral reef rehabilitation procedures which consist of four stages, namely preparation, implementation, monitoring/evaluation, and maintenance (Sceleractinia, 2015). All stages of these activities will be a space for empowered fishermen to learn and share responsibilities. Therefore, the role of the fisherman groups in this project is more of the subject (actor) and not merely an object.

The concept of community empowerment in coral reef rehabilitation in Baurung encourages the development within the fisherman group level. Therefore, participation has an important role as stated by Ife in Muhdar, et al. (2014) who mentioned that one of the key principles of community development is participation. The importance of participation in community empowerment activities, especially in coral reef ecosystem improvement is shown by the Nature Conservation Forume Putri Manjangan group from the Pejarakan Village Community, Buleleng, Bali who actively participated in implementing, maintaining and taking care of rehabilitated coral reefs in order to 
restore the sustainability of coral reefs in Indonesia, specifically in Pejarakan Village (Nyoman et al., 2017).

The significance of the community participation in environmental management activities will ensure that those activities are more relevantly formulated for the actual problems and needs of the community. It is in line with White's et al. (1994) study which outlines that there is no successful natural resource management without involving local communities as the direct users of natural resources.

After running less than two years as it was first implemented in 2016, coral reef rehabilitation activities in Baurung did not proceed optimally. It was informed that one of the root problems lies in the low fisherman participation, which affects the final result of the program. There has been no scientific research yet that discusses the coral reef rehabilitation activities. Therefore, this study will focus on discussing the detailed activities and participation of fisherman groups as the objects of the study.

\section{Method}

The research was conducted on August 16 - August 22, 2020 in Tamo and Baurung, Baurung Village, Banggae Timur District, Majene Regency, West Sulawesi Province. It was the location for coral reef rehabilitation activities in 2016. This study uses a qualitative approach. The qualitative approach results descriptive data in the form of written and spoken forms from the research participants and their observed behavior. Creswell (2016:4) suggests that the qualitative approach aims to explore and understand characters of individuals or groups who are ascribed to social or humanitarian problems. This statement is in line with the research objectives in the current study, which aims to reveal the implementation of coral reef rehabilitation activities which have been carried out in Baurung and the participation of the Fisherman groups who have been directly involved during the activity. These data will be obtained using interview, observation and documentation techniques.

Qualitative research does not use the term population, but sources, participants or informants. According to Bungin, 2007:76, research participants could be the subjects who understand the object information as actors or other parties who understand the research object. Therefore, the informants who are considered very knowledgeable about coral reef rehabilitation activities are the implementing parties who are the lecturers from the Study Program of Aquaculture and Animal Science at the University of West Sulawesi as well as the heads of the Fisherman group called Ponggawa sasi which was divided into two small groups: Sipatuo and Samaelo. The informants were selected using purposive sampling technique and the analysis in this study uses an interactive analysis from Miles \& Huberman (2007:19-20), which consists of reducing, presenting and verifying data, as well as drawing conclusions.

\section{Result and Discussion \\ Implementation of Coral Reef Rehabilitation Activities}

Based on the results of the Research and Development Center of the Indonesian Oceanology Institute in 2003 , the very good category of coral reefs in Indonesia are only about $6.83 \%$ left, the good condition was approximately $25.72 \%$, the moderate condition was around $38.87 \%$ and the poor condition was 30.58\% (Suharsono, 2003 in Zulfikar \& Soedarma, 2008). The data clearly illustrates the condition of coral reef ecosystems in Indonesia which has been quite alarming, considering their function which have rich 
JPPM (Jurnal Pendidikan dan Pemberdayaan Masyarakat), 8 (2), 2021 - 150

Muhammad Muhtaj Qadir, Budhi Gunawan, Iskandar

benefits. Therefore, coral reefs need special attention and handling to reduce the potential damage.

The ecosystem management of coral reefs aims to prevent more severe coral damage and to repair the damaged coral. Therefore, coral rehabilitation efforts are needed to improve its condition. According to Bakosurtanal (2000) several attempts must be made to conserve the damaged coral reefs by taking steps to restore them. Restoration of damaged coral reefs itself is not simple because it requires relatively large costs and takes a long time. One of the possible recovery methods and has also been applied is coral reef rehabilitation.

Rehabilitation of coral reefs naturally takes a quite long time. Intervention is needed to accelerate coral growth by using certain engineering technologies such as artificial reef technology and coral transplantation technology. Transplantation techniques can restore coral reef ecosystems and can multiply coral colonies. Based on Zulfikar and Soedharma (2008), coral transplantation techniques have been widely used in several provinces in Indonesia.

Implementing transplantation techniques in coral reef rehabilitation activities is considered very essential to restore and improve the damaged coral reef ecosystems in several areas in Indonesia. This is supported by Guldberg's statement in Kuffner (2002) who argues that coral transplantation is necessary because coral reefs are globally degrading at an alarming rate.

Coral reef rehabilitation which has been carried out in Baurung are a form of coral reef ecosystem management to overcome the damage to coral reefs in Banggae Timur. It as one of the sub-districts which experienced serious coral reef damages. The data from the Office of Marine and Fishery Service in Majene (2013) measured the percentage of coral coverage in all sub-districts in Majene and it showed that Banggae Timur District had 20-30\% coral coverage (critical), Banggae District with 15\%-30\% of coral coverage (critical), Pamboang District with 16\%-35\% of coral coverage (critical), Sendasan District with 10\%-25\% (severely damaged) and the other district with 35\%-50\% coral coverage left (average).

Coral reef rehabilitation activities in Baurung are carried out in several stages including preparation, implementation, monitoring/evaluation, and maintenance. It follows the coral reef rehabilitation guideline issued by the Ministry of Marine Affairs and Fisheries (2015) which explains that the stages in carrying out rehabilitation consist of the preparation stage, the implementation stage, the monitoring/evaluation stage and the maintenance stage.

The first stage, which is also called the preparation stage, comprised two steps of activities, namely observation and dissemination. Observations were made to find fisherman partners who were willing to take part in coral reef rehabilitation. They were later assigned into two groups (the Sipatuo and Samaelo groups). Dissemination, added to this, attempted to provide them with awareness and knowledge on the importance of maintaining coral ecosystems and how to overcome damages to coral reefs. Preparation is the initial stage in empowering fisherman groups through a series of existing activities (observation and dissemination). Based on Kairan (2010), the empowerment process can be carried out in two ways: individually (individual self-empowerment) and collectively (collective self-empowerment). By forming two groups of fishermen in coral reef rehabilitation activities in Baurun, the empowerment process was carried out collectively. 


\section{JPPM (Jurnal Pendidikan dan Pemberdayaan Masyarakat), 8 (2), 2021 - 151}

In the second stage, the implementation stage, training and technical guidance on coral transplantation were conducted to equip them with the procedures to restore corals in damaged areas. The training is carried out collectively by following several steps, including:

1. Training on finding parent colonies;

2. Training on how to take coral fragments from the parent colonies;

3. Training on the process of transporting parent corals;

4. Training on creating and preparing transplant tables;

5. Training on creating a substrate as a place for coral fragments to attach;

6. Training on binding coral fragments to substrate posts;

7. Training on attaching coral fragments to the substrate;

8. Training on relocating the coral from land to sea at coral transplant sites.

By joining various kinds of training which involved hands-on practices at this stage, the process of empowering fishermen groups was ensured. This was proven by a direct learning process or, rather called, learning-by-doing performed by fishermen. The learning process aimed at enhancing their capacity and knowledge about coral reef ecosystems as well as techniques to overcome ecosystem damage in the future. It is expected to create independent management by the fishermen. According to Soetomo (2006), independence increases people's understanding on the importance of natural resources so that they will make an effort to maintain and preserve them, especially if these natural resources provide economic benefits.

The next stage is the monitoring and evaluation stage. The monitoring stage in coral reef rehabilitation activities in Baurung aims to measure the condition of transplanted corals. The monitoring activities which have been routinely carried out include measuring water quality such as temperature, salinity, color and measuring coral conditions such as survival rate and coral growth rate. The coral growth rate is only about $0.2 \mathrm{~mm}-8 \mathrm{~mm}$ per year (Stoddard, 1969, in Nybakken, 1992). During this two-year program, the largest coral growth size which has been recorded was around $15 \mathrm{~cm}$ with an estimated growth rate of about $1 \mathrm{~cm}$ per month. This result is similar to that of the study conducted by Iswara (2010) in Kelapa Island with six-month observations which found that the growth rate of the corals are approximately $0.85 \mathrm{~cm} / \mathrm{month}$. Meanwhile, Tioho (2013) with one-year observation in Kalasey waters found that its growth rate is in the range between $0.81-0.94 \mathrm{~cm} /$ month and Mompala et al. (2017) with their fourmonth observation in Karaoke waters found the coral growth rate is around 0.96 $\mathrm{cm} /$ month.

Monitoring activities were administered out twice a month by involving all groups of fishermen. It is mentioned in the guidelines for coral reef rehabilitation by the Ministry of Marine and Fisheries (2015) that the monitoring activities of coral growth rate should be conducted ideally from the first week with a period of every two months or according to the needs. In addition to monitoring, evaluation is also carried out together once a month to identify problems and find solutions to each existing problem. The evaluation stage discusses monitoring schedules, replanting plans for loose or damaged fragments, and reinforcing a sense of belonging for the community to achieve program sustainability.

The last stage is the treatment stage. Rehabilitation activities are basically adopting the coral transplantation method and it was not only about the stage of transferring seedlings and binding to the substrate, but there is also a very important 
treatment stage. The treatment stage aims to clean the substrate from disturbances of other creatures such as macroalgae. In addition, maintenance serves to keep coral seedlings on the transplant rack/table, thus it could reduce corals' mortality and maintain their optimal growth rates.

The maintenance attempts in coral transplantation activities according to Jipriandi et al. (2010) include:

1. cleaning settled sediments and biofouling organisms, especially algae attached to fragments and transplant media. Cleaning is performed manually or using particular tools such as brushes.

2. removing or separating the dead corals from living corals to minimize the transmission process and to repair the damaged shelves immediately.

3. arranging tiller stands which are detached from transplantation shelves or those which position is not upright/tilted. The loosened or fallen corals are conditioned to their original position.

4. adjusting time for maintenance activities with the observation (monitoring) and the waters' conditions. If possible, this procedure should be performed regularly, once a week during three months. In the waters with rapid growth of biofouling, the cleaning attempts should be conducted more frequently.

The maintenance stage in coral reef rehabilitation activities in Baurung is in line with monitoring activities, but the intensity is more frequent. Based on the respondents' information, the maintenance stage of coral reef rehabilitation activities was always scheduled regularly and carried out by all of the involved parties. The respondents explained the steps of maintenance activities which include:

1. cleaning the sediment which has been attached to and settles on the reef;

2. cleaning corals from adhering organisms;

3. removing or separating dead corals;

4. fixing the coral or table position which shifts due to the currents;

5. re-binding the dropped or tilted fragments.

Maintenance was carried out once a week and it is scheduled every Friday or Saturday depending on which day the members of the Sipatuo and Samaelo fisherman groups got their free time.

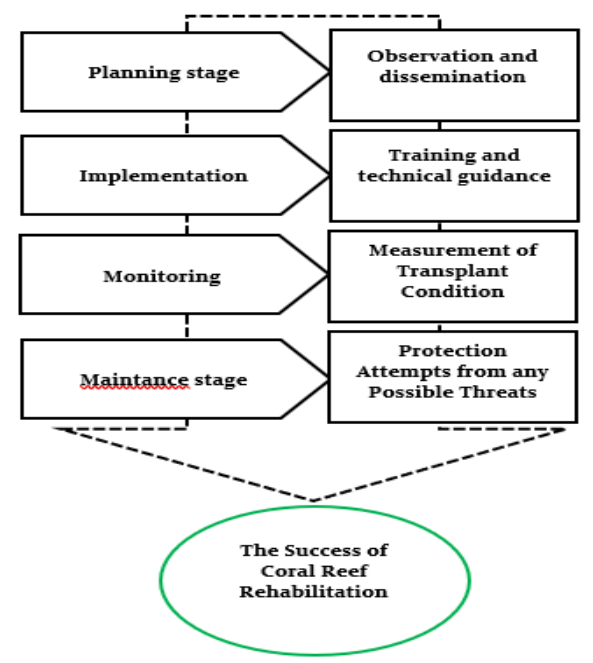

Figure 1. The Stages of Coral Reef Rehabilitation Activities in Baurung Village 
JPPM (Jurnal Pendidikan dan Pemberdayaan Masyarakat), 8 (2), 2021 - 153

Muhammad Muhtaj Qadir, Budhi Gunawan, Iskandar

\section{The Fisherman Group Participation in Coral Reef Rehabilitation Activities}

In the previous sub-chapter, it has been explained that the coral reef rehabilitation activities in Baurung Village consist of four stages, namely the preparation stage, the implementation stage, the monitoring stage and the maintenance stage. The focus of the previous discussion was on the description of activities at each stage. The discussion in this part, on the other hand, will focus on the element of fisherman group participation in each stage of coral reef rehabilitation activities carried out in Baurung Village starting from the preparation stage to the maintenance stage.

Coral reef rehabilitation activities do not only attempt to manage coral reef ecosystem but also to focus on community empowerment efforts, as mentioned in its objectives. Community empowerment is closely related to participation. This is conveyed in Adisasmita's (2006) study which states that community participation is a social empowerment activity which is oriented on achieving the desired outcomes within the community.

Participation is considered a highly important component in the development activity. All stages of development, therefore, must be filled with community participation, as Suryana (2010) says that participation is a community involvement in all stages of the development process that exists within a community group. It starts from analyzing the situation, making plans, implementing management, monitoring and evaluating, determining the program's benefit distribution to ensure equality and justice. From this statement, there is a strong implication that community participation should be at every stage of the development program. In accordance with the requirement, coral reef rehabilitation in Baurung should ideally involve the participation of fisherman groups at all stages of the activities.

In the preparation stage for coral reef rehabilitation activities in Baurung, the participation of fisherman groups was quite good in welcoming this program. In the observation stage, the fishermen voluntarily offered to take part in the activities. At the dissemination stage, the same response was also demonstrated by all members of the fishermen. In its implementation, all members of the fishermen, 22 people, participated in the dissemination and information session. According to Budyatna (2001), dissemination is highly necessary in a community empowerment program. The most effective dissemination is the one carried out by government officials and assisted by local community leaders. In coral reef rehabilitation activities in Baurung, the dissemination was carried out by the government officials of the Majene's Office of Marine and Fishery Services and the implementing parties from the Aquaculture and Animal Science Study Program at the University of West Sulawesi. The implementing parties provided an opportunity for each member of the fishermen who wanted to convey his aspirations and ideas during the dissemination. In this case, the implementing parties or project executors seeks to provide space for all of the fisherman members to communicate ideas so that the underlying concepts behind the activities came from the fisherman members.

After the preparation stage has been carried out, the rehabilitation activities continued to the implementation stage. According to the implementing parties, all fisherman members participated in the training and were able to absorb the information well. Besides, the implementing parties always provided spaces for fisherman members 
as much as possible to raise questions if there are any unclear things. This space was well utilized by fisherman members, where they actively gave feedback and inputs.

In the implementation stage, the fisherman group's participation is not only limited to a thought-provoking contribution, but also a donation. The fisherman members voluntarily donated several pieces of iron as the materials for making transplant tables. According to Davis in Sastripoetro (1986), community participation can be in various forms. First, the participation can be in terms of thoughts. Thoughts are considered as a type of participation at the first level where the community participated by giving ideas which aims to achieve the desired goals. Second, energy is a type of participation where the community contributed groups and individuals' energy to achieve the desired goals. Third, mind and energy is a type of participation where the community combine their energy and thoughts in a group to achieve the desired goals. Fourth, expertise is a type of participation where the individuals' expertise is the most anticipated element to achieve the desired goals. Fifth, goods are a type of participation where the community provided an item to help achieve the desired goals. Lastly, funding is a type of participation where the community provides fresh money for the program to achieve the desired goals. This type of participation is commonly carried out by certain groups only. In the implementation stage, in general, the participation of fishermen groups is in the good category.

The next stage is monitoring and evaluation stages. In this stage, the participation of fisherman groups is not described as a good category and tends to decrease. The results of interviews showed that, the intensity of participation from fisherman members slowly decreased at the monitoring stage, although it was not quite significant. A high figure of fishermen participation at the monitoring stage was only observed at the beginning of the stage up to the sixth month. After that period, the participation of several fisherman members continued to decline. In the theory of participation, there are several factors that could influence community participation. The nature of these factors may support the success of a program but may also hinder the activity or program itself.

Generally, the factors affecting participation are divided into two types, which are internal factors and external factors. Internal factors refer to the factors that come from the individuals as in Slamet's (1993) opinion which outlines that individual behavior is closely related and determined by sociological characteristics such as age, education level, jobs, income level, length of stay in a particular area and occupancy status. Meanwhile, external factors are the factors from outside the individuals or community. Sunarti (2003) adds that external factors can result from the stakeholders, including all parties who have their own interest and have a certain influence on the programs. The parties involved from the external side comprised the government officials, the supporting team, the organizers, the village officials and leaders. Even though the number of participants was decreasing, monitoring activities continued with minimal personnel. To keep the program running, the implementing parties and each group leader always strived to carry out the monitoring agenda based on the arranged schedule. The uncertain number of members participating in monitoring activities made the implementing parties overwhelmed because the number of resources was not balanced with the workload during this stage.

The last stage refers to maintenance. The maintenance stage is a crucial stage because the activities are related to maintaining and caring for the transplanted corals 
from various kinds of disturbances. Maintenance in this project was carried out intensely, which was conducted once a week. The high intensity demands continuing participation of all parties, especially the fisherman groups. In fact, the fisherman groups demonstrated the similar participation to what happened in the monitoring stage. There was also a decrease in the participation interest of some fisherman members. Another impact from the decreasing fishermen's participation related to the intensity of the maintenance activities, which were conducted randomly. This has brought a direct impact on some of the fragments which were eventually damaged and died.

Due to the decreasing participation of fishermen's groups, the schedule of maintenance activities turned uncertain: once in two weeks and even only once a month. This problem has been discussed and evaluated but it remained occurring repeatedly. Such phenomena at the maintenance stage can once again be caused by both internal and external factors. If seen with a broader perspective, community participation could be influenced by several fundamental elements (Firmansyah, 2009) such as: (1) Community's self-confidence, (2) Community solidarity and social integrity, (3) Social responsibility and community commitment, (4) Willingness and ability to change/improve conditions and to stand on their own feet, (5) Community or individual initiatives which are accepted and recognized as the community's property, (6) Pure public interest, at least this interest is considered 'public' within the concerned community, as opposed to private interests. One, or more than one factor mentioned above, could contribute to the declining participation among some fisherman members in the maintenance stage during coral reef rehabilitation activities in Baurung Village.

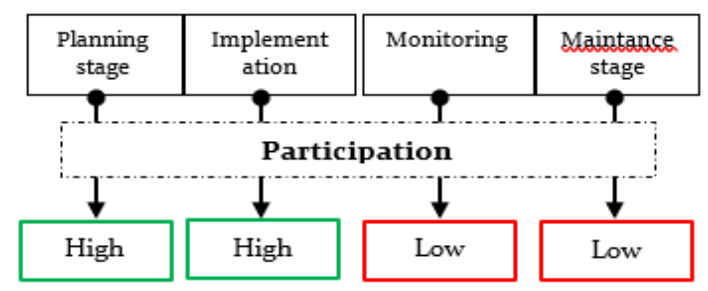

Figure 2. The Participation Scheme of Fisherman Group in Every Stage of the Activities

\section{Conclusion}

The coral reef rehabilitation activities which were carried out in Baurung Village have implemented a set of procedures of coral reef rehabilitation. In addition, in terms of empowerment, the implementing parties have provided the opportunity for fisherman groups to enhance their capacity and awareness through exchanging opinions, practicing and sharing equal responsibilities. However, the decreasing participation of some group members in the monitoring and maintenance stages caused those stages could not work as intended, and it contributed to the failure of achieving the ecological and social goals. This demonstrates the real evidence of the importance of community participation in an activity or program.

This study basically focused on the identification of the coral reef rehabilitation activities carried out in Baurung and the participation of fisherman groups who have been directly involved in the programs. The finding of the current study suggests that further research needs to reveal broader aspects such as the results and benefits of coral reef rehabilitation activities in Baurung. Moreover, it should seek to find out more 
JPPM (Jurnal Pendidikan dan Pemberdayaan Masyarakat), 8 (2), 2021 - 156

Muhammad Muhtaj Qadir, Budhi Gunawan, Iskandar

systematic information regarding what factors led to the decreasing participation of several members of the fisherman groups, as discussed in this study.

\section{References}

Adisasmita, R. (2006). Membangun Desa Partisipati. Yogyakarta : Graha Ilmu.

Ahmad Muhtadi Rangkuti, Muhammad Reza Cordova, Ani Rahmawati, Yulma, Hasan Eldin Adimu. (2017). Ekosistem Pesisir dan Laut Indonesia. Penerbit Bumi Aksara. Jakarta.

Asri. (2009). Analisis Faktor Yang Mempengaruhi Partisipasi Nelayan Dalam Pengelolaan Lingkungan Wilayah Pesisir Kota Palopo. Universitas Cokroaminoto Palopo. Prosiding Seminar Nasional.

Bungin B. (2007). Penelitian Kualitatif:Kumunikasi, Ekonomi, Kebijakan Publik dan Ilmu Sosial Lainya. Jakarta : Kencana

Creswell, J. W. (2016). Research design: pendekatan kualitatif, kuantitatif, dan mixed. Yogyakarta: Pustaka Pelajar.

Dahlah, Uar, N. (2016) 'Kerusakan Akibat Aktivitas Manusia Pada Terumbu Karang', Majalah Geografi Indonesia, 23(45), pp. 5-24.

Dhahiyat, Yayat, Djalinda Sinuhaji, and Herman Hamdani. (2003). Struktur Komunitas Ikan Karang di Daerah Transplantasi Karang Pulau Pari, Kepulauan Seribu (Community Structure of Coral Reef Fish in the Coral Transplantation Area Pulau Pari, Kepulauan Seribu). Jurnal Iktiologi Indonesia 3.2 (2017): 87-94.

Dinas Kelautan dan Perikanan Kabupaten Majene. (2013). Profil Potensi Kelautan dan Perikanan Kabupaten Majene. Majene

Faculty of The Louisiana State University and Agricultural and Mechanical College. Hamilton College.

Giyanto, G., Muhammad, A., Tri, A., H., Agus, B., Muhammad, H., Abdullah, S., \& Marindah, Y., I. (2017). Status Terumbu Karang di Indonesia 2017. COREMAP-CTI Pusat Penelitian Oseanografi - LIPI.

Haris, A. (2011). Transplantasi Karang Acroporidea Pada Subtrat Alami, Omni Akuatika $\mathrm{X}$ (12) 2011: pp33-42.

I Nyiman Januarsa \& Oktyas Muzaky Luthfi. (2017). Community Based Coastal Conservation In Buleleng, Bali. Economic and Social of Fisheries and Marine Journal 04(02), pp. 166-173.

Iswara, S. (2010). Analisis Laju Pertumbuhan Dan Kelangsungan Hidup Karang Acropora Spp., Hydnopora Rigida, Dan Pocillopora Verrucosa Yang Ditransplantasikan Di Pulau Kelapa, Kepulauan Seribu. Skripsi. Departemen Manajemen Sumberdaya Perairan. FPIK-IPB. Bogor.

Jipriandi, A. Pratomo, H. Irawan. (2010). Pertumbuhan Karang Acropora Formosa dengan Teknik Transplantasi Pada Ukuran Fragmen Yang Berbeda. Program Studi Ilmu Kelautan, Fakultas Ilmu Kelautan dan Perikanan. Universitas Maritim Raja Ali Haji.

Johan, O. 2012. The Survival od Transplanted Coral on Pyramid-shape Fish Shelter on The Coastal Water of Kelapa and Harapan Island, Kepulauan Seribu, Jakarta. Indonesia Aquaculture Journal 7 (1) pp 79-85.

KKP. (2015). Pedoman Rehabilitasi Terumbu Karang (Sceleractinia). Direktorat Konservasi dan Keanekaragaman Hayati Laut. Jakarta 
JPPM (Jurnal Pendidikan dan Pemberdayaan Masyarakat), 8 (2), 2021 - 157

Muhammad Muhtaj Qadir, Budhi Gunawan, Iskandar

Lammers, P.L. (2017). The challenges of community-based conservation in developing countries-A case study from Lake Alaotra, Madagascar', Journal for Nature Conservation. 40, pp. 100-112

Lentz JA. (2012). Developing A Geospatial Protocol for Coral Epizootiology. [Disertation]. The Departement of Oceanography and Coasta Science.

Mahfud Effendy dan Firman Farid Muhsoni. (2018). Ibm Transplantasi Terumbu Karang Kelompok Masyarakat Desa Kombang dan Masyarakat Dusun Gili Labak Sebagai Media Meningkatkan Potensi Wisata Selam. Universitas Trunojoyo. Madura

Muhdar, Jamaludin, \& Irwansyah. (2014). Partisipasi Masyarakat Dalam Program Corporate Social Responsibility PT. Arutmin Nort Pulau Laut Coral Terminal Kotabaru (Studi tentang Program Koperasi Serba Usaha Madani Kotabaru). Jurnal Bisnis dan Pembangunan, 1 No 1, 22-28.

Mustari, Mohamad. (2012). Pengantar Metode Penelitian. Yogyakarta: LaksBangPRESSindo

Mompala, K., Rondonuwu A.B., Rembet, U.N.W.J. (2017). Laju pertumbuhan karang batu Acropora sp. yang ditransplantasi pada terumbu buatan di Perairan Kareko Kecamatan Lembeh Utara Kota Bitung. Jurnal Ilmiah Platax. Vol 5(2). Hal 234242.

Netty Dahlan, Sigit Herumurti, Suwarno Hadisusanto. (2015). Kajian Kerusakan Lingkungan Akibat Aktivitas Manusia Pada Ekosistem Terumbu Karang, Studi Kasus : Pantai Ngurbiot Ohoi, Kecamatan Kei Kecil, Kabupaten Maluku Tenggara, Provinsi Kepulauan Maluku. Universitas Gadjah Mada.

Nybakken, J. W. (1992). Biologi Laut Suatu Pendekatan Ekologi. Alih Bahasa : M. Eidman, Koesoebiono, D.G. Bengen dan M. Hutomo. Gramedia, Jakarta.

Ramses. (2018). Kondisi dan keragaman karang hias di Perairan Pulau Sarang dan sekitarnya, Kecamatan Bekalang Padang, Kota Batam. SIMBIOSA. Vol (2): 57-66.

Slamet, Y. (1993). Pembangunan Masyarakat Berwawasan Partisipasi. Surakarta: Sebelas Maret University.

Soedharma, D., \& Arafat. (2006). Strategi Pengelolaan Ekosistim Terumbu Karang dan Mangrove Untuk Menunjang Kestabilan Ekosistim Bahari di Perairan Sulawesi Selatan dan Sulawesi Barat. Makalah Seminar, Makassar.

Suharto, Edi. (2005). Membangun Masyarakat Memberdayakan Masyarakat, Kajian Strategis Pembangunan Kesejahteraan Sosial dan Pekerjaan Sosial. Bandung : PT. Refika Aditama

Sugiyono. 2012. Metode Penelitian Kombinasi (Mixed Methods). Penerbit Alpabeta Bandung

Sunarti. (2003). Partisipasi Masyarakat Dalam Pembangunan Perumahan Secara Kelompok. Jurnal Tata loka. Semarang. Planologi. UNDIP

Syakir, M., Kasim, M., Syafyudin, Y., Deddy, S., \& Nurul, A. (2015). Pembelajaran Pengelolaan Terumbu Karang di Sekitar Lokasi Pengeboran Minyak dan Gas Lapangan Tiaka, Tomori, Sulawesi Tengah. Jurnal Ilmu Kelautan dan Perikanan, Vol. 25(2), pp. 88-95.

Soetomo. (2006). Strategi-Strategi Pembangunan Masyarakat. Pustaka Belajar. Yogyakarta.

Sjafrie NDM. (2010). Nilai Ekonomi Terumbu Karang di Kecamatan Selat Nasik, Kabupaten Belitung. Oseanologi dan Limnologi di Indonesia 36 (1) : 97-109 
JPPM (Jurnal Pendidikan dan Pemberdayaan Masyarakat), 8 (2), 2021 - 158

Muhammad Muhtaj Qadir, Budhi Gunawan, Iskandar

Tulungen, J.J. (2003). Panduan Pengelolaan Sumber Daya Pesisir Berbasis Masyarakat. Jakarta : USAID-BAPPENAS.

Tuwo, A. (2011). Pengelolaan Ekowisata Pesisir dan Laut. Pendekatan Ekologi, Sosial Ekonomi, Kelembagaan, dan Sarana Wilayah, Brillian Internasional. Sidoarjo.

Tioho, H., Paruntu, C.P. dan Patrich, H. (2013) Ketahanan Hidup Dan Laju Pertumbuhan Karang Scleractinia Yang Ditransplantasi Pada Rataan Terumbu Perairan Kalasei, Kabupaten Minahasa, Sulawesi Utara.Aquatic Science \& Management, Vol. 1, No. 2, 111- 116.

White, A.,L.Z.Hale, Y. Renald and L. Cortesi. 1994. Collaborative and Community Management of Coral Reefs: Lessons from Experience. Kumarian Press, Connecticut, USA.

Widayatun. (2011). Peran Masyarakat Dalam Pelestarian Terumbu Karan dan Peranya Terhadap Peningkatan Kesejahteraan. Jurnal Kependudukan Indonesia. Jakarta

Zulfikar, Soedharma D. (2008). Teknologi fragmentasi Buatan Karang (Caulastrea Furcata dan Cynarina Lacrimalis) Dalam Upaya Percepatan Pertumbuhan Pada Kondisi Terkontrol. Jurnal Natur Indonesia, 10 (2) : 76-82 